\title{
The Boy and the Bicycle (an old TB story)
}

\author{
Franco M. Zambotto
}

The 11 o'clock sunshine filtered between the branches of the trees standing guard by the wayside, casting their shadows onto the gravel road as the boy cycled slowly along, looking in the ditch at the first yellow flowers that had appeared there just a few days earlier.

These yellow summer flowers, which grow spontaneously on the banks of ditches, are a typical feature of the fields of the plain; they love to bask in the sun, while they tend to shy away from dark, shadowy areas. The boy thought to himself "here they are again; that means summer is back with its colours, its warmth, its days of endless sunshine, its butterflies."

At that instant, a butterfly fluttered near the boy's face, gently brushing against it. He watched it for a few seconds until it dropped out of sight, zigzagging into the grass lining the ditch. The boy pedalled even more slowly than before; it was almost as though time itself were grinding to a halt following the passage of those silent wings. The boy, his hands on the handlebar, instinctively kept the bicycle on track as he gazed at the surface of the water close to where the butterfly was now coming to rest on a white flower. He also spotted two dragonflies hovering an inch or so above the surface of the water that was flowing lazily in the direction of the sea. That area of water was like a miniature airport, but completely soundless. All that moved were the leaves of the surrounding trees stirring in the late spring breeze that came from the East before drifting away in the direction the sun sets.

Suddenly, from behind the bend came the sound of hooves and cartwheels turning on gravel. The travelling salesman was returning after completing his round of local houses.

He walked alongside a four-wheeled cart, covered and equipped as a small shop. Its engine? A horse. After all, these were the very early days of door-to-door selling.

On hearing his voice, women would come outside to buy their sugar, coffee, cheese, oil, salt and pepper in short, all the basics for their humble kitchens.

People did not buy vegetables because their gardens were full of them. In fact, vegetables were not even sold at the time, and greengrocers' shops were still a thing of the future. Nature, carefully tended, provided fruit and vegetables in season. During the winter months, on the other hand, there would only be walnuts, dried figs, carobs, boiled and dried chestnuts and peanuts. On Sundays, there would also be persimmons.

Another travelling salesman, who would wait for the women coming out of Mass, sold a few types of fruit and vegetables that were otherwise impossible to get hold of, such as oranges, mandarins, bananas and persimmons.

After the cart had gone by, the boy took a quick look up the road and then set off again, pedalling fast and taking the curve at a rate for the sheer thrill of seeing the gravel fly up and spray into the water on the right. Before him lay the final stretch of straight gravel road. At this point the ditch on either side narrowed sharply and there appeared fields of vines, the plants forming a canopy overhead. A little jump was all it took and you were in them. Above the verdant leaves, the sun beat down, while below them there was cool shade, giving shelter to every manner of insect and a pleasant cool sensation to any passerby.

This was the last stretch before reaching Vittorio's house.

Vittorio's house stood next to the road and could be accessed through two gateways (both without an actual gate): a large one big enough for carts to pass and a small one for people. Glancing round quickly and without stopping the boy cycled through the larger entrance. His forehead was bathed in sweat. He cycled over to the well, flung his bicycle to the ground, grabbed hold of the chain and started slowly pulling up the heavy bucket from the depths of the water at the bottom of the well. Having retrieved it, he placed it on the side of the well before tipping it towards his face and, without stopping, thirstily drinking his fill. The cool water after the hot cycle ride along country lanes refreshed him in the same way as the shade of the vines that had greeted him along the last stretch of road. The cool water seeping inside him attenuated the surrounding heat.

Then, scampering up a little ladder, he threw himself into the hay in the hayloft. It seemed enormous, that hayloft. A throne on high from which to observe his world - a world made up of simple things and marked by the rhythm of the seasons; a world of heat, or of cold; a world bounded by the distant rows of poplars quivering in the wind, beyond which he had never ventured.

It was also a world inhabited by animals: rabbits that, unafraid of people, could be stroked, prolific cats that had made the barn their home, blackbirds ever on the lookout for ripening fruit, and farmyard hens constantly pecking at the ground in search of something to eat. After the hayloft, the boy hopped onto the swing that hung, its seat secured to taut ropes, from the branches of a large tree known as the "albera". Indeed, in the 


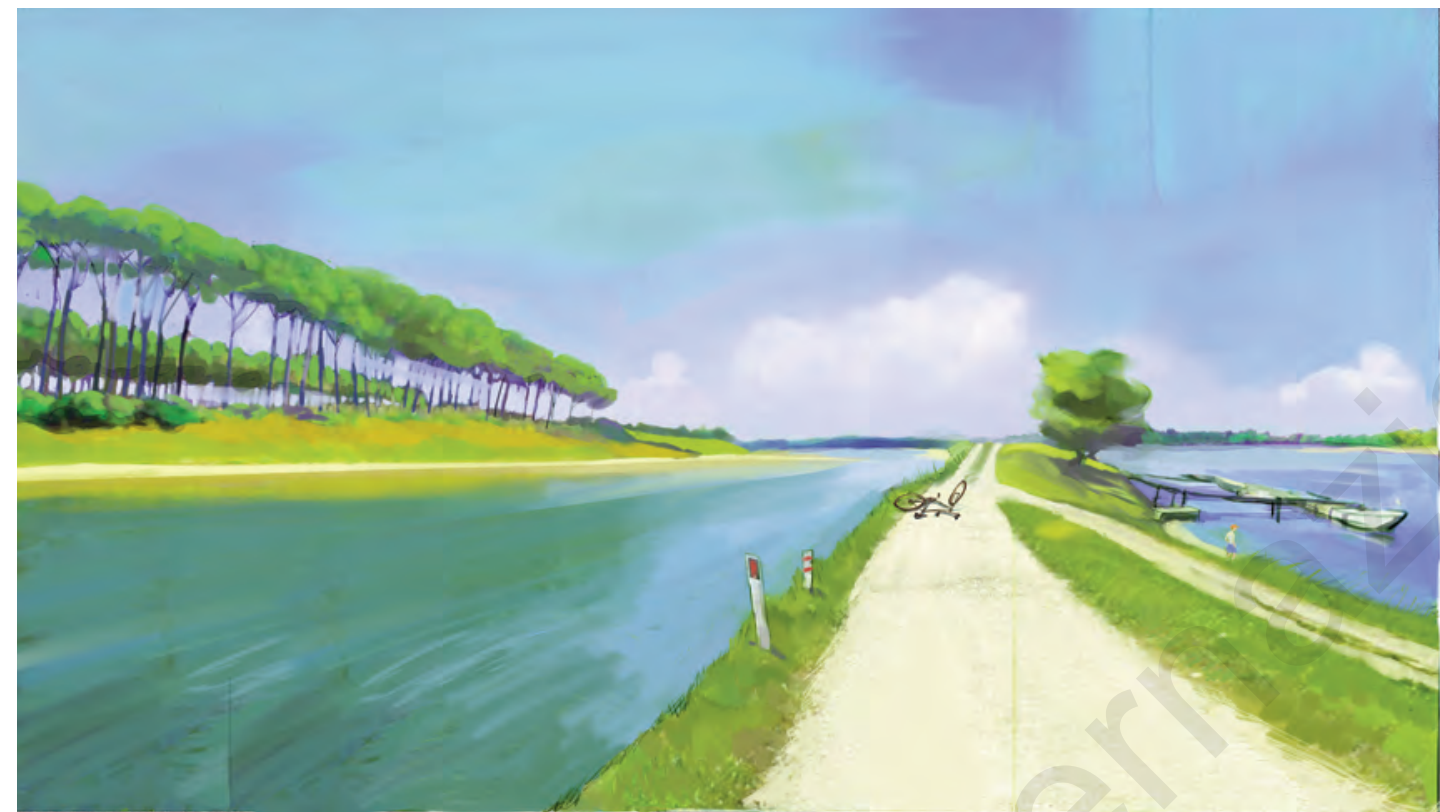

"The bike on the bank of the river" by Marco Ceruti.

local dialect, large trees were always referred to in the feminine. The abundant shade they provided certainly seemed to encourage the emergence of life.

In that natural paradise, the chimes of the church bells in the village could be heard in the distance, marking out the passing of time.

The days here passed in the joyful and carefree manner known to those who enjoy close contact with nature and live it to the full, perceiving its every quiver, change and moan, as though every plant were telling its story, every blade of grass commenting on the black crickets that hurried past and into their tiny dens. And then of course there was the watery world of the ditches where occasionally a pike would dart among grasses bobbing lazily in the slow stream. Further on, a carp might be warming itself in the sun. A few dragonflies would hover an inch or so above the surface of the water. This particular habitat, flanking every country lane, was also home to an almost infinite variety of insects. Echoing the distant pealing of the bells, the sound of crickets, too, marked the fall of evening. As if wanting to enjoy the last rays of the setting sun, they would take position on the thresholds of their underground homes - small clearings, concealed among the blades of grass, which allowed them to get into and out of their dens.

The fall of evening meant home time - time to return to the village.

Then it was children's TV followed by supper. The three of them seated around the table: his father, his mother and him.

His father did not have much to say at the table. He seemed lost in a thousand thoughts, none of which would have meant much to a young boy distracted by children's TV and cartoons - a boy whose thoughts were taken up by other things entirely: the wonder of nature, which was a daily discovery for him, and that wonderful little box that showed him pictures of the wider world.

Straight after supper, he jumped down, crossed the road, and entered his maternal grandparents' home, where washing lay drying on the simple stove and the coffee pot bubbled.

There was a little cup just for him. Sugar, a precious commodity, was spooned out sparingly by his grandmother from an old jar with a rim that had practically been worn away by so much opening and closing.

The grown-ups talked among themselves about the happenings of the day and the past few days, and speculated about the fortunes and activity of the farm in the coming season.

At about half past nine, the boy went to bed, in the warmth of the evening breeze.

It was all magical: the gentle passing of time, the sun, the trees, the grass, the water, the sky. One day, however, the countryside games were interrupted by Guido, Vittorio's oldest son. Guido picked the boy up and perched him on the crossbar of his bicycle, telling him he was taking him into the village. The road, the ditch, the fish, the insects and the wind and sun seemed somehow subdued, almost as though they had disappeared. The gravel road, along which Guido pedalled furiously, was their only companion.

They stopped at the gate of the house, got off the bicycle and, hand in hand, made their way up to the first floor.

On opening the bedroom door, the boy saw his father lying in bed, near to which there was an oxygen cylinder. Silently, several relatives moved aside. The father took the boy's hand and murmured a few words of farewell and comfort. They were to be his last.

Just as they had left it, they hurried back to the coun- 
tryside, flying along on the bicycle.

That night the boy slept at Vittorio's house, as he did the following night and other nights after that.

On one of the afternoons that followed, each sunnier than the one before, he heard the sound of bells, dif- ferent from the usual ones. It was a sound that would become very familiar to him.

He was not taken to the funeral, but instead left to play amid nature and the sunshine.

Tuberculosis had destroyed another family.

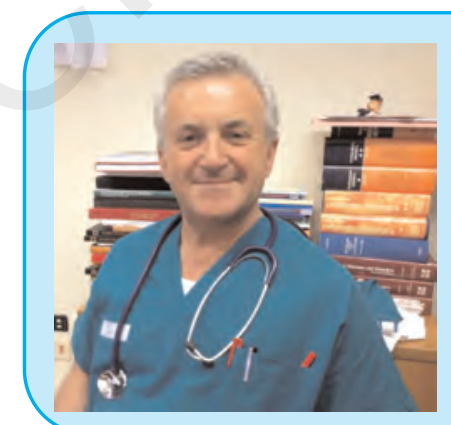

Franco Maria Zambotto is a physician specialized in Respiratory diseases. He's the Director of the Department of Pneumology at the general Hospital of Feltre, Belluno, Italy. He's the President of the Veneto branch of the Italian Association of hospital pneumologists (AIPO). He received a classic education at high school, and he is passionate about moral phylosophy and bioethics. Recently, participated in a multidisciplinary working group named "A Gentle Right" devoted to propose a law on the relationship of care between medical doctors and terminally ill people. He's a read expert gourmet, and a veteran of the Italian Alps Army. During spare time he gives his help as a volunteer in an association for civil protection. As an amateur writer loves to write poems and short stories. 